\title{
Muito Barulho por Nada
}

Sergio Corrêa da Costa. Crônica de Uma Guerra Secreta. Nazismo na América: A conexão Argentina. Rio de Janeiro: Ed. Record, 2004.

por Iuri Cavlak ${ }^{1}$

Publicado no ano passado e disponível na maioria das livrarias do Brasil em 2005, o livro do diplomata, historiador, ex-Ministro (interino) das Relações Exteriores do Brasil e imortal da ABL vem prestar um desserviço ao movimento de aproximação entre os dois maiores países da América do Sul. Deliberadamente, o autor atribui a este livro um título pomposo que pouco corresponde ao seu conteúdo, enganando o leitor, que fatalmente se sentirá logrado.

O assunto principal deveria versar sobre a presença de espiões e refugiados nazistas na Argentina, durante os dois governos de Juan Domingo Perón de 1946 até 1955, ainda que o autor trabalhe com um contexto histórico que anteceda este marco. Bastante informativo, é mencionado grande número de alemães presentes ou que circulavam nos altos escalões do governo argentino. Buenos Aires, de fato recebeu vários nazistas fugitivos após o término da Segunda Guerra Mundial até pela sua tradição de acomodar estrangeiros, embora o motivo principal fosse engajá-los no processo de industrialização e desenvolvimento militar, que efetivamente nunca se voltaria contra o Brasil, como sugere Costa. Guerra secreta, no caso, é o elemento ausente da realidade histórica, pois como o autor afirma - tanto o Vaticano quanto os Estados Unidos - ajudou o escape de autos oficiais que serviram a Hitler para Buenos Aires, sabendo do que se passava por ali. Além disso, tanto o

\footnotetext{
${ }^{1}$ Docente da Rede Pública de Ensino do Estado de São Paulo, graduado em História pela Universidade Estadual Paulista (Unesp-Assis) e Mestre pelo programa de História Social da Unesp-Assis.
} 
Brasil quanto outros países latino-americanos receberam elementos nacionais socialistas e Vargas por alguns momentos até direcionou seus discursos para o apoio das "novas forças que estavam tomando conta da Europa".

Neste sentido, o autor se perde nas mais de quinhentas páginas que compõe o livro, desviando toda hora seu fio argumentativo. São mais de quarenta páginas para explicar que o Brasil era o principal comprador de produtos alemães na década de trinta. Cinqüenta páginas para descrever a presença de espiões nazistas na América Central, no Paraguai, na Bolívia, no Chile e Uruguai. Da página noventa e um até a página cento e noventa para explicitar a operação dos espiões no Brasil, a criação da CIA e do Serviço Secreto Britânico. Os supostos planos de Hitler para o mundo são estudados na segunda parte do livro. A História da Argentina é contada sem nenhuma articulação ao assunto principal, e a chamada "conexão argentina" só é diretamente contemplada a partir da página trezentos e setenta e um. O leitor fica a se perguntar o que tem a ver a "guerra secreta" da Argentina nazificada contra o Brasil, assunto muito alardeado na sobrecapa com a história de amor de Olga Benario e Luis Carlos Prestes (p. 35) ou os alemães fantasiados de poloneses como pretexto para a invasão germânica na Polônia (p. 38).

Além disso, as afirmações discutíveis ou equivocadas do autor estão em todo lugar. Alguns exemplos: na página onze, é dito que os governos que sucederam Peron foram mais nacionalistas que esse. Na página treze, que a "vocação legítima do Brasil é a democracia" (como se a dialética histórica fosse constituída de essências, e não de forças em luta). Mais adiante, o juízo é de que o governo argentino sustentou a França de Vichy (p. 44). A forma e a circunstância disso nos são vedado saber. Plínio Salgado, o chefe do fascismo brasileiro, é descrito como "um homem de boa fé" (p. 125) e líder de um importante movimento "antidemocrático e anti-semita", que o autor faz questão de colocar entre aspas. O por quê das aspas é uma incógnita. Será que na verdade os integralistas, na visão do autor, eram democráticos e sionistas? Filinto Muller, que pessoalmente ou a seu mando torturou e matou presos políticos na época do Estado Novo no Brasil é caracterizado como “um íntegro 
descendente alemão" (p. 144). Outras afirmações seguem por esse diapasão. A Universidade Argentina "era uma ativa base de apoio ao peronismo" (p. 267). Justamente uma instituição que os peronistas mais intervieram com brutalidade, caçando docentes e prendendo alunos, pois se tratava de um foco de resistência ao regime. Adiante, "qualquer estudioso da história argentina começara por observar que o país nasceu predestinado a grande potência" (p. 270). Como predestinada? Existe predestinação na história? "Tal como a Alemanha, a Argentina sentia a necessidade de espaço vital (Lebensraum) e deveria bater-se por ele" (p. 282). Dois contextos completamente diferentes: da Alemanha nazificada na primeira metade do século XX e o da Argentina, país periférico do capitalismo. Quando das eleições presidenciais na Argentina em fevereiro de 1946, o autor afirmou que a chapa de oposição a Peron era "uma chapa correta" (p. 302). Correta de que ponto de vista? O que seria uma agenda política correta naquele contexto? Nas páginas 140 e 400, o Brasil é caracterizado como naqueles anos, o país "mais desarmado da América Latina". Fica a pergunta: mais desarmado que o Paraguai? Que a Bolívia? Que o Peru? A República Velha é caracterizada como um regime democrático (p. 285). Bem, se esse período da história do Brasil foi democrático, então grande parte da ciência política brasileira tem de rever seu conceito de democracia. Neste sentido, a UDN, sempre a clamar por golpes militares também é chamada de partido bastante democrático (p. 136).

No aspecto da linguagem o autor também comete alguns deslizes. Muitas vezes chegando ao coloquial: "Ondina não exitou em meter o pau em Hitler" (p. 107). Também o abuso da interjeição "ora", utilizada seguidamente nas páginas 321(duas vezes), 326, 331, 335, 336, 339 e outras seguintes. Quando diz que Peron foi apoiado pelos descamisados argentinos, não se decide a forma de grafar esse conceito, uma vez que "descamisados" aparece sem aspas na página 330, depois com aspas na página seguinte e finalmente em itálico na página 303. Ao velho estilo do historicismo alemão do século XIX, o autor trabalha para mostrar "a verdade, nua e crua". (p. 470). 
Seu ex-oficio de diplomata chega a ser super valorizado. Diz que a Segunda Guerra Mundial foi ganha pelos aliados "pela espionagem" (p. 177), além de ter sido "um jovem irresponsável" (p. 50), excelente espião, "muito antes de James Bond ter ensinado o caminho". O que o autor chama de "lições de James Bond" aparece seis vezes no livro. O chamado herdeiro político de Hitler, Martin Borman aparece com sua morte confirmada nos escombros de Berlim em 1945, depois de várias especulações a respeito (p. 488) para depois ser objeto de análise do autor como pessoa que sobreviveu a Guerra e imigrou para a Argentina (p. 504).

Assim, fica notória a má qualidade do texto e o sentimento abertamente anti-argentino do mesmo. A presença deletéria nazista em solo portenho é acompanhada desde as primeiras implantações de empresas germânica em Buenos Aires, a partir de 1918, e de militares transladados de 1919 até 1928, isto é, no período da Republica de Weimar, onde sequer os nazistas detinham ainda a hegemonia da sociedade civil, quiçá do Estado. 